Proceeding of the International Conference on Advanced Science,
Engineering and Information Technology 2011

\title{
Assessment of Bekok River Water Quality Status and Its Suitability for Supporting the Different Uses: A Review
}

\author{
Lee Mao Rui , Mohamad Ali Fulazzaky ${ }^{*}$ \\ Department of Water and Environmntal Engineering, University Tun Hussein Onn Malaysia \\ Parit Raja, Johor, 86400, Malaysia. \\ ${ }^{\#}$ Tel.:+60 7-4537906, E-mail: maorui_86yahoo.com.my \\ *Tel.:+60 7 4537332,E-mail: alif@uthm.edu.my
}

\begin{abstract}
The river's water flow from the upstream area that is represent by the Bekok dam. The water flows into the sea through the Sungai Simpang Kanan and Sungai Batu Pahat. Bekok' river flows through various types of land use including agricultural with oil palm estate and rubber estate. From the review visit carried out on the river pollution found there from the sources such as fertilizer into the ground and dumped it into the Bekok' river, waste water draining from users around the city Yong Peng waste flowing into Bekok' rivers. the existence of livestock chicken, cattle and goats in commercial, waste disposal centred in Yong Peng area (500 meters) from the Bekok' river and factory built near the Bekok' river. The impact of this situation is affecting the human's health. The aggravated problems of water quality in Bekok' river has inspired this research to determine the safe level pollution of heavy metals. The formulation of the water quality standards are commonly considered either the water utilization purposes or the water quality degradation. The water quality evaluation system (WQES) is used to evaluate the available water condition that distinguishes into two categories i.e., the water quality index (WQI) and water quality aptitude (WQA). This analysis is provides for the local authorities in managing the river water quality and to warm water users that the water pollution will influence human's drinking water and it will involved younger generation.
\end{abstract}

Keywords - Bekok River, pollution sources, water quality

\section{INTRODUCTION}

Rivers have been known to be one of the important water sources in our life. It has provided water supplies for the population and industry, a means of navigation route for materials and commences (Neal et al., 2005). Besides that, rivers also serve as boundaries between state and this is particularly so in the case of Malaysia (DID, 2009).

As in Malaysia, rapid development in recent years has affected the water quality of many rivers. These rivers have become polluted due to the wastes that have poured into the rivers. For instance, the number of polluted rivers within the period of ten years has increased from seven in 1990 to thirteen in 1999. On the other hand, the number of pollution free rivers has decreased from 48 in 1990 to 35 in 1999 (Zulkifli and Norhayati, 2001). Therefore, it is important to prevent and control the river pollution and to have available information on water quality for effective management.

Bekok' river is an important river which supplies potable water to the community of Batu Pahat with the superficies $1878 \mathrm{~km}^{2}$. The basin is approximately $57 \mathrm{~km}$ long and $6 \mathrm{~km}$ wide and has a catchment area of $350 \mathrm{~km}^{2}$, approximately $19 \%$ of the Batu Pahat state. The catchment area of Bekok' river inhabited around 29,000 people in 2009. The annual average flows are $7 \mathrm{~m}^{3} / \mathrm{s}$ at Jalan Yong Peng, Labis.

Bekok River is one of the raw water resources for Batu Pahat treatment plants which supply treated water for domestic, institutional, commercial and industrial use. The Bekok' river and its basin have played important roles in economic development within Batu Pahat state where majority of the important features in supporting economic development within the state are located in this basin. The river dictated to some extent the pattern of development within the area, where it provided the main source of fresh 
water, and the floodplains were fertile and useful for early agriculture activities (DOE, 2010).

\section{MATERIAL AND METHOD}

\section{A. Study Area}

In recent year Bekok river faces several water quality problems with the concentration of iron and aluminium high as $110 \mathrm{mg} / \mathrm{l}$ and $290 \mathrm{mg} / \mathrm{l}$ respectively (DOE, 2010). The $\mathrm{pH}$ values were as low as 2.5 which exceeded the limits set out by the Interim National Water Quality Standards for Class II Rivers (DOE, 2010). This has caused significant interruptions in the operation of water treatment plants at Yong Peng $2 \& 3$ as well as Sri Gading and Parit Raja treatment plant to produce sufficient potable water to the district of Batu Pahat. The problem becomes critical in 2007 started after a period of long drought from mid January to 23 March 2007. During the heavy rainfall after the drought, the operation of Parit Raja plants force to be shut down on 26 March 2007 due to substantial amount of ammonia, aluminium, iron, manganese and acidity found in the raw water (DOE, 2010).

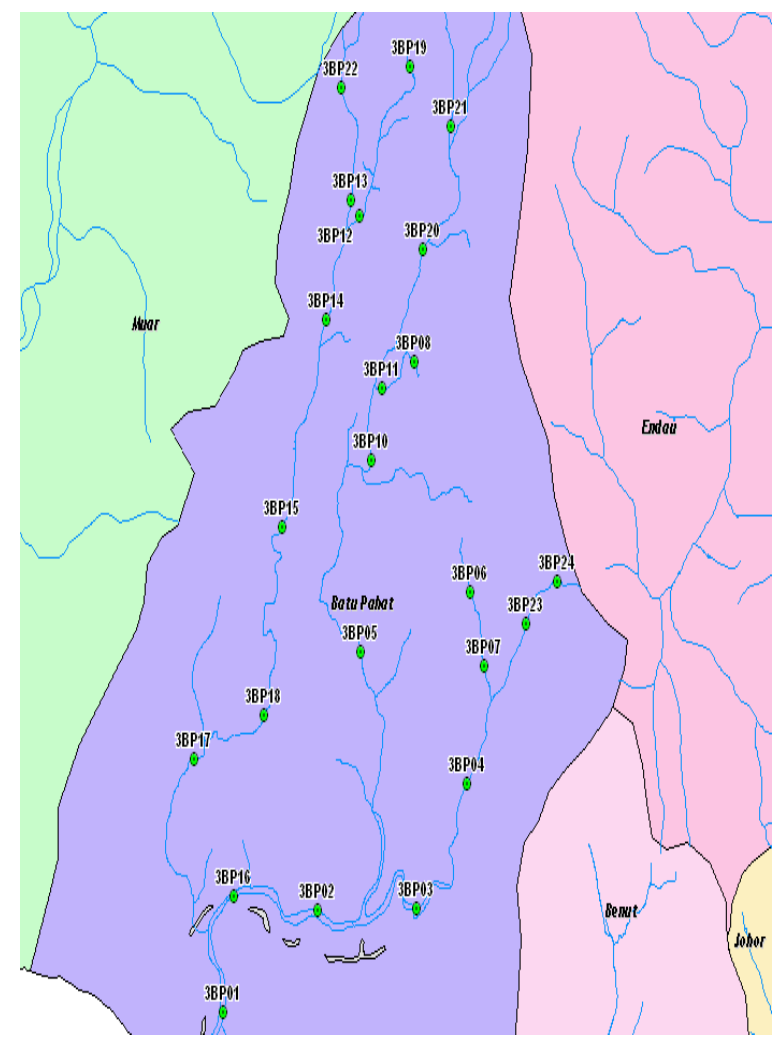

Fig. 1 Location of Sampling Analysis

\section{B. Sampling Analysis}

The samples collected at station 3BP05, 3BP10 and $3 \mathrm{BP} 21$ and it were analyzed. That are 16 parameters selected for the analysis are Dissolved Oxygen (DO), Chemical Oxygen Demand (COD), Ammoniac Nitrogen $\left(\mathrm{NH}_{3}-\mathrm{NL}\right)$, Nitrate Nitrogen $\left(\mathrm{NO}_{3}{ }^{-}\right)$, Phosphorus Phosphate $\left(\mathrm{PO}_{4}{ }^{3-}\right)$,
Colour, Conductivity (COND), Suspended Solid (SS), Hydrogen ion concentration ( $\mathrm{pH})$, Algae, Cadmium (Cd), Mercury (Hg), Coliform, , temperature, Pesticides and Non Pesticides.

\section{ANALYSTS}

The data that collect by the laboratory test will be analyst manually. The water quality evaluation system (WQES) is used to evaluate the available water condition that distinguishes into two categories that is water quality index (WQI)(Table.1) and water quality aptitude (WQA)(Fig.3). Application of WQES is a part of water quality monitoring process that aims to convert the data to information. Since the data of water quality may be interpreted individually in accordance with the experiences and knowledge of personal expert, the interpretation of water quality data becomes doubt and uncertain information (Fulazzaky 2005). The WQES is envisaged to possess the operational procedure standard (OPS) for generating the data to information. The first important of WQES is used to assess the status of water degradation in the stream to support the local authority in managing of water quality. This status is commonly referred as WQI. The second important is to identify the suitability of water, refer as water quality aptitude (WQA), for differ uses and its ecosystem.

Table. 1 Classification of water quality index*. *Source: Oudin et al. 1999 modified by Fulazzaky 2008

\begin{tabular}{|c|c|c|}
\hline Index (range) & Quality & Classes \\
\hline$(>81-100)$ & Very Good & Blue \\
\hline$(>61-80)$ & Good & Green \\
\hline$(>41-60)$ & Moderate & Yellow \\
\hline$(>21-40)$ & Bad & Orange \\
\hline$(>0-20)$ & Very Bad & Red \\
\hline
\end{tabular}

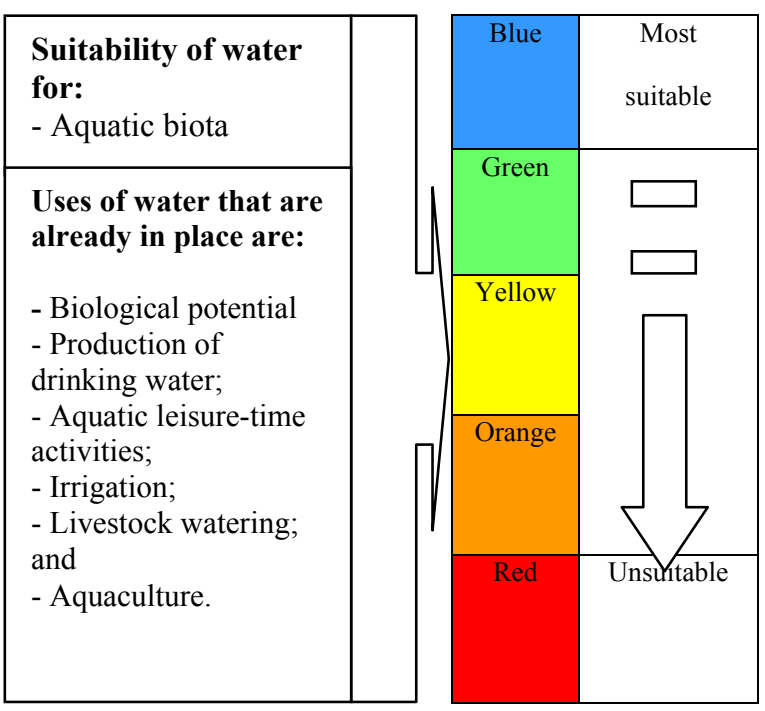

Fig. 3 Classification of water suitability for uses and aquatic biota* * Source: Oudin et al. 1999 modified by Fulazzaky 2008 


\section{IV.EXPECTED OUTCOMES AND CHALLENGES}

\section{A. Expected Outcomes}

This study recommends to the local authority to envisage the certain priority in order to handle the problems of pollution. The objective will achieve that is to assess the status of water quality in the Bekok' river and to identify the suitability of water providing the water uses and its ecosystem for warning in performing of water to different uses and to advice the related local governments in improving of water quality.

\section{B. Challenges}

Some action should be taken in order to improve and protect the river. The challenges include the implementation of a balance water quantity strategy. The aspects to be considered are as follow:

1) Land matter : To improve the river, it may require the acquisition private lands especially in the private estate at the upper parts of the catchment.

2) Enforcement and monitoring activities: The and concerned agencies such as department if irrigation drainage, department of environment, land survey department, local Authority have to play their roles and identify the gaps in their function and responsibilities to ensure all aspects are well covered and considered.

3) Public involvement: To increase the awareness of the local community, NGO and stakeholders on the needs to protect and maintain the river.

4) Cooperation: Good cooperation between all agencies is required in handling and resolving the problems encountered within the river basin.

\section{CONCLUSIONS}

The assessment of water quality of Bekok River is based on the Interim National Water Quality Standards. Out of 5 sampling sites, sampling site 1 located at demonstrated the most polluted while others are slightly polluted. It was identified that the major sources of pollution are from domestic sewage, animal waste and agricultural wastes. Soil erosion from construction site and urban runoff are also identified as sources of pollution within the study area. Water quality control strategies should be taken out in helping the watershed to be less polluted. Effective and practical approach like pollution prevention, environmental education and legislation enforcement can be applied in upgrading the water quality of the river basin. Hopefully, through these strategies, the basin may have a better life in future.

\section{ACKNOWLEDGMENT}

I would like to express my sincere appreciation to my supervisor, Assoc. Prof.Ir.Dr. Mohamad Ali Fulazzaky for their guidance, inspiration, encouragement and friendship at various stages of the preparation of the research. Without their continued support and interest, this seminar paper would not have been the same as presented here.

\section{REFERENCES}

[1] Department of Environment (DOE) (2003). Water quality management in Malaysia. Kuala Lumpur: DOE Documents.

[2] Department of Environment (DOE) (2004). Kajian Pencegahan Pencemaran Dan Peningkatan Kualiti Air Sungai Melaka, Kuala Lumpur : DOE Douments.

[3] Department of Irrigation and Drainage (DID). (2007) Selangor river basin management plan 2007-2012. Kuala Lumpur:DID publications.

[4] Department of Irrigation and Drainage, Klang River Basin Environmental Improvement and Flood Mitigation Project, Final Report by Dr. Nik \& Associates. DID, 2002.

[5] Abdul Rahim Bin Awang (1997), Penentuan Beban Pencemaran Sungai Semberong, Parit Raja, Batu Pahat, Kuittho.

[6] Radin Maya Saphira (2003), Kajian Pencemaran LogamLogam Berat Terpilih Di Sungai Bekok, Kuittho.

[7] Tan Yu Chai (2001), Kualiti Air Sungai Semberong, Batu Pahat, Johor, Kuittho.

[8] Jabatan Alam Sekitar (1993), Kualiti Air Sungai, Kementerian Sains, Teknologi Dan Alam Sekitar, Malaysia.

[9] Ann Anton \& Lee Jin (2004), Integrated Water Resources management in Malaysia : Experience and Practices : Proceedings of the $1^{\text {st }}$ Malaysian Water Forum, $8-10$ June 2004, Kuala Lumpur Malaysia.

[10] T.H.Y.Tebbutt (1998), Principles of Water Quality Control, Professor of Water Management, School of Construction, Sheffield Hallam University.

[11] E. Roberts Alley (2000), Water Quality Control Handbook, McGraw-Hill.

[12] Jabatan Penilaian Dan Perkhidmatan Harta, Kementerian Kewangan Malaysia,Laporan Pasaran Harta (property Market Report), Kuala Lumpur, Malaysia.

[13] W.Wesley Eckenfelder,Jr (1989), Industrial Water Pollution Control, McGraw-Hill, Civil Engineering Series.

[14] Nelson L. Nemerow (1995), Zero Pollution for Industry, Waste Minimization Through Industrial Complexes, Professor of Industrial Waste Management, University of Miami.

[15] Paul L.Bishop(2000), Pollution Prevention : Fundamental and Practice, McGraw-Hill, Civil Engineering Series.

[16] Teng Tioon Tow, Fera Fizani Ahmad Fizri, Norli Ismail, Fazilah Ariffin \& Anees

[17] Ahmad (2008), Proceedings International Conference on Environmental Research and Technology (ICERT' 08), School of Industrial Technology, Universiti Sains Malaysia. 